\title{
The production and reception of Deon Meyer's works: An evaluation of the factors contributing to bestseller status
}

Beth le Roux and Samantha Buitendach

Department of Information Science, University of Pretoria

\section{Introduction}

Deon Meyer is a household name in South Africa as a bestselling crime fiction author. He is described as "famous", as "celebrated", and as "the first of his kind" in popular articles on his work. Journalists and academics alike laud his achievements, arguing that "(s)inglehanded, he has created a new literary genre for himself - the Afrikaans thriller" (Davis, 2013). Meyer himself argues that "( $t$ )here has never been a culture in Afrikaans of thriller writing" (cited in Davis, 2013) and that he was "the first to publish, back in 1994" (Meyer, n.d.). His success has seen him labelled both the "king of local crime fiction" and the "father" of this genre (Warnes, 2012: 986). Apart from popular interest, Meyer has also received more academic interest than any other South African popular fiction writer to date (see, among others, articles by Warnes, 2012; Primorac, 2011; Andersson, 2004; Wessels, 2007; Drawe, 2013; Torres, 2012; Naidu, 2013). Few have now not encountered his fastpaced detective stories featuring strong male characters like Benny Griessel, Mat Joubert and Thobela Mpayipheli. He is now so ubiquitous that a commentator on Beeld's website recently complained that the newspaper's book reviewers appeared to have no other frame of reference for popular fiction ('Jaydee', 2013).

Meyer's worldwide recognition and global sales figures mean that he has attained a status rare among South African authors - his novels are bestsellers, and he is now able to write full-time and live off the proceeds of his writing. But what exactly has made this author so popular, when many other South African authors continue to struggle for global (or even local) recognition? This article explores how and why Meyer's career has evolved in the way that it has, in an attempt to answer the question of what has made him so successful. The focus is not, like so much academic analysis of fiction, on the form or content of Meyer's work, but rather on the wider social context, and in particular the publishing and reception 
history of this author. This social context, we argue, is not 'background'; rather, it is essential to the positioning of an author and the reading of his or her works.

Significantly for his production and reception history, Meyer writes in Afrikaans. In South Africa, the trade or general leisure reading market is small, with just under half of local titles being produced in Afrikaans and accounting for around R150 million in sales annually (PASA, 2011). Sales per title are modest, with 'bestsellers' often selling no more than 5000 copies. To achieve international recognition and larger sales, a title must first be translated into English. However, the local book-buying market is loyal to both authors and publishers, once they have developed a taste for their books.

\section{Playing with Fire: Decision-making around Meyer's first title}

Meyer regularly describes his first novel, Wie Met Vuur Speel (WMVS), as being like having "a brother in jail - you can't deny it, but you don't talk about it" (Meyer 2013). This novel was published by Tafelberg in 1994, and its origin story has become something of a legend in Afrikaans literary circles. As Meyer tells 'Die Storie Agter Die Storie' ('the story behind the story') - and he has repeated this in several interviews since 1995 - after having published several short stories in magazines like Huisgenoot, he decided to write a crime novel because this is the genre he has always preferred to read. Not wanting to put too much effort into writing a novel that might not be published, he decided to first approach a publisher and discuss the potential interest in such a title. An early interview has him recounting the story as follows: “Ek bel vir Tafelberg-Uitgewers. 'Wat soek julle?' Die ou sê so 'n Afrikaanse avontuurboek, in die trant van Wilbur Smith, middelmoot, lekkerlees. Toe begin ek maar skryf." ("I phoned Tafelberg Publishers. 'What are you looking for?' The guy said an Afrikaans adventure story, in the style of Wilbur Smith, mainstream, easy-reading. So I just began writing.") (cited in Joubert, 1994; our translation). Danie Botha and Frederik de Jager of Tafelberg confirmed that they were interested in publishing thrillers and crime fiction, and that they thought it would sell. Over the following two years, Meyer wrote a manuscript titled 'Icarus' and submitted it. It was accepted relatively quickly, but took another two years before it was finally published as Wie Met Vuur Speel in 1994. 
As this story implies, Meyer had a keen awareness of the Afrikaans literary marketplace and of the key players in the industry even before he began writing. The publisher he approached, Tafelberg, had been an imprint of Nasionale Pers (the holding company, Nasionale Boek or NB, is owned by Media24) since 1959, with a focus on general trade titles in Afrikaans: "Tafelberg het veral bekend geraak as die uitgewery van groot romans" ("Tafelberg became known especially as the publisher of big novels") (Venter, 2006: 319; our translation). As regards the specific genre, the local industry saw some production of crime fiction in the apartheid years (Le Roux, 2013), especially in Afrikaans, but it appears that this tapered off in the waning years of apartheid. Venter's (2006: 526) analysis of Afrikaans fiction production for the period 1990 to 2005 , shows that $75 \%$ of all titles published were popular fiction with about $6 \%$ falling into the sub-genre of crime fiction. Thus, in 1994, Meyer was not alone in writing in this genre, as 28 other crime fiction titles had been published in Afrikaans that year. In 1992, Human \& Rousseau had started to specialise in this area, with re-editions of for example the works of Doc Immelman from the 1980s, and after 1995 with new authors like Alex Muller (the pseudonym of Eleanor Baker), Chris Moolman, and Nic Tredoux. Tafelberg only produced, on average, one title a year in this category (mostly translated novels).

But, while crime and detective fiction grew in popularity internationally throughout the twentieth century (Sutherland, 2007: 56), in South Africa the most widely read popular fiction sub-genre was, in fact, romance (Venter, 2006). Although not entirely without precedent, Meyer's proposal offered something different to publishers: a popular genre that would appeal to both male and female readers, and that would incorporate both an interest in current socio-political events and growing concerns about the crime rate after the 1994 democratic elections. Warnes (2012) describes the reasons for the genre's enduring popularity:

Publishers and markets are well established, the plot-driven nature of the novels means they often sell well in translation, and there exists a voracious appetite for work from new locations. Locally, the democratisation of crime ... has meant that writers and readers have found common ground in the need to find fictions to explore a persistent source of anxiety. 
WMVS was immediately popular, if not a runaway success. It was welcomed as a contribution to the corpus of post-apartheid Afrikaans literature and, specifically, to the crime genre, and described as "unputdownable" and "exciting" (see anonymous review, Die Burger, 1994). Some reviewers revealed their familiarity with Tafelberg's backlist and publishing philosophy, referring to the broader list of new Tafelberg titles: "Met Wie met vuur speel bevestig Tafelberguitgewers opnuut sy verbintenis tot toeganklike, gewilde Afrikaanse prosa. ... Deon Meyer se kortverhale verskyn die afgelope vier jaar in populêre tydskrifte. Sy romandebuut is duidelik ook aan só 'n vertelwyse ontleen en sou waarskynlik tot vyf jaar gelede nie Tafelberg se publikasielys gehaal het nie!" ("With Wie met vuur speel, Tafelberg has reaffirmed its commitment to accessible, popular Afrikaans prose ... Deon Meyer's short stories have appeared for the past five years in popular magazines. His debut novel is clearly indebted to a similar narrative style and would probably not have made Tafelberg's publishing list five years ago!") (Van der Westhuizen, 1995; our translation).

Apart from readers' familiarity with the publisher and author (due to his short stories), Meyer's debut was also affected by how the book was positioned in the market, or in other words by paratext. Paratext (Genette, 1991) refers to "the means by which a text makes a book of itself and proposes itself as such to its readers" - the decisions taken around packaging, cover design, and so on. As publisher, Tafelberg positioned WMVS very much within the genre of crime fiction, a "spannende avontuurverhaal" ("thrilling adventure story") as the blurb stated. The blurb went on to describe the plot, emphasising aspects of crime and violence: “... Ragel and Dirk find themselves in an extremely dangerous situation, and are forced to call upon the services of the enigmatic Ivan Malan, master of disguise, manipulation and other sinister activities. When danger calls, his arsenal - known as the 'cabinet of death' - lies at the ready..." (blurb, WMVS). The typical wording for the genre creates expectations among readers of the emotive experience of suspense, adventure and danger. Marketing theory emphasises the importance of categorisation and of evoking emotions in consumers, as emotion influences the buying decision (Lamb et. al, 2006).

Van der Westhuizen argues that "(t)he physical appearance of the book is the first visible marketing strategy employed by the publisher", and an author or title can gain status by how the book is presented (2000, cited in Kleyn, 2013: 69). The packaging thus assists in 
creating a product that is desirable, as Scholtz states: "Boeke moet begeerlik, verbeeldingryk verpak word. 'n Omslag moet vra om gekoop te word" ("Books must be desirably, imaginatively packaged. A cover must ask to be bought") (cited in Van Zyl, 2000; our translation). Tafelberg also emphasised the genre through the cover design. The design was not inspired, featuring a generic drawing of a skyline, beautiful women, tough men, and sportscars, within the crosshairs of a gun. While this may not be a very original design, it is not unusual to find Afrikaans fiction trading on conventional cover designs, especially those used in the United States. Tafelberg also retitled the novel, specifically with a view to better sales, as they felt that one-word titles were not popular. Meyer has criticised this decision, arguing that Icarus would have been a better title, and would have fitted better with his later titles, Feniks and Orion (Meyer, 2013).

Figure $1<$ cover image $>$ (with permission from NB)

All the aspects of the paratext - including cover imagery, title and wording - assisted in positioning this book within its generic conventions. Paratext, as Genette points out, is a result of deliberate decision-making. In the case of Meyer's debut, "the publisher took all the decisions", which is the usual situation as publishers see paratext as lying outside of the author's domain. He notes that, "just for the record, I did not agree with any of them", elaborating: "In all due fairness to the publisher, it was the first suspense novel in Afrikaans for three decades, and they had no experience in publishing that sort of thing. Moreover, I was so grateful for being published at all, that I accepted all their decisions. Both publisher and author have learnt a lot in the meantime, and I have final say in both title and cover, and get much better advice" (Meyer, 2013).

Reviews of WMVS were not entirely positive, but tended to see the good points as outweighing the bad ones, as in the following example:

Deon Meyer het sy huiswerk gedoen, en daarin geslaag om 'n eersterangse aksieverhaal te skryf wat alle elemente van dié genre op oortuigende manier met mekaar verbind. Dit is nie 'n geringe prestasie nie, veral aangesien dit 'n debuutroman is hierdie. Die lakmoestoets vir romans in hierdie genre is dat die leser dit nie kan neersit as jy eers begin lees het nie. Nouja, ék kon dit nie neersit nie... ("Deon Meyer has done his homework, and succedded in writing a first-rate action 
story which convincingly combines all elements of the genre. It is no small feat, especially seeing as it is a debut novel. The litmus test for novels in this genre is that the reader cannot put them down once they've started reading. Well, I couldn't put it down...") (Pakendorf, 1995; our translation)

If the reviews are anything to go by, Tafelberg's and Meyer's own position within Afrikaans media networks (as he previously worked for Die Volksblad) appears to have contributed to the widespread circulation of the novel. This insertion into mainstream distribution and discussion networks is a significant factor when considering the sales and reception of any book, but especially fiction titles. So, the title was reviewed in all the main Afrikaans newspapers, including by respected literary commentators or academics, such as the literary historian Hendrik van Coller. Moreover, while there was little actual marketing of the first title, apart from publicity through reviews, Meyer was also inserted into the national Afrikaans literary debate. For instance, he started to take part in book discussions, such as a literary evening hosted at the Nasionale Pers Boeksentrum.

The first edition sold a respectable total of 3591 copies (NB, 2013). It thus created a reputation for Meyer - crucial brand awareness - and provided a fertile context for his next title. As the blurb for his second novel, Feniks, notes, "Deon Meyer het met één boek, Wie met vuur speel, 'n reputasie as een van die beste spanningskrywers in Afrikaans verwerf' ("Deon Meyer has, with one book, Wie met vuur speel, created a reputation as one of the best thriller writers in Afrikaans"; our translation).

\section{Building a local market}

With the publication of his second novel, Meyer moved publishers, from Tafelberg to Queillerie - although in effect this was a move between imprints of the same over-arching publishing house, NB, which has published almost all of his work to date. Frederik de Jager, the publisher at Tafelberg, began working with Hettie Scholtz at Queillerie at around this time, and it seems that Meyer followed him. This also led to the start of a fruitful working relationship between Meyer and his editor, Etienne Bloemhof. While WMVS had been edited and managed by Danie Botha at Tafelberg, at Queillerie Meyer encountered Bloemhof. As Meyer acknowledges, his publishing history since then has run parallel with 
Bloemhof's career moves, because "he's the best in the business" (Meyer, 2013; Venter, 2006: 310). This was the start of a defining relationship that would shape his career.

But Feniks itself was not a huge success, with the first edition selling just 1387 copies (NB, 2013). This is probably due more to its marketing at the time than to the quality of the book itself - the title introduced the popular character of detective Mat Joubert. With improved marketing and paratext, later editions of this title would sell somewhat better (with 5407 copies for the 2004 edition, and 10834 for the 2008 edition). Once again, the paratext played a role in positioning the title within the genre, this time as a "speurroman" or detective fiction. The original cover design is bold and abstract: a black cover, with the title in red and yellow lettering, and a small red image of a phoenix. The blurb described the plot in simple terms, and added information on the author with an author photograph. This reveals the growing importance of Meyer's own branding as an author, even at this early stage of his career.

Figure 2: <cover image >

One of the key forms of publicity for Feniks was author interviews, and Meyer also began to appear at literary events. Reviews thus began to engage with Meyer as an author and, typically, as a fellow consumer of crime fiction - a significant marketing technique showing empathy with one's readers. A review described the reception of the book as particularly positive and depicted Meyer's reaction as gratitude (Engelbrecht, 1996). Another review focused on Meyer's reading of the genre: "Dat Deon wel in dié genre beland het en ná die ongekende sukses van Feniks die etiket as Suid-Afrika se speurverhaalskrywer omgehang word, kan waarskynlik teruggevoer word na sy verslaafdheid aan 'n skrywer soos Ed McBain" ("That Deon ended up in this genre and received the label of South Africa's detective story writer after the unsurpassed success of Feniks can evidently be ascribed to his addiction to writers like Ed McBain") (Britz, 2000; our translation).

While the first edition of Feniks was not a huge bestseller, the title was significant for Meyer's later success: for one thing, because of the relationship that developed with Bloemhof, his editor, and for another because this was the title that brought him to the 
attention of a literary agent, Isobel Dixon. Dixon ensured that the translation rights to Feniks were sold, and the English-language rights in particular meant that his work became more accessible to a world-wide audience. Winterbach has described the pressure on Afrikaanse writers to be translated, in order to gain respect and recognition: "As an Afrikaans writer you will only be taken seriously when read in translation" (cited in Kleyn, 2013: 135). Because of the international visibility and sales of Dead before Dying, the translation of Feniks, Meyer's success should really be dated to the publication of Feniks, and not WMVS. In fact, later reviewers would often mistake Feniks for his debut title, and, later, academics have repeated the error (e.g. Warnes, 2012). Thus, when Orion was published by Human \& Rousseau in 2000, reviewers tended to compare it only to the previous novel - also ignoring a collection of short stories that had been published in the meantime, Bottervisse in die Jêm (J.P. van der Walt, 1997):

"Meyer, soos die geval was in sy debuut, Feniks, demonstreer in Orion die wins van sy agtergrond as koerantman." ("Meyer, as in his debut, Feniks, demonstrates in Orion the benefit of his background as a journalist") (Olivier, 2000; our translation)

"Met sy spanningsverhale het Deon Meyer so stil-stil een van die land se gewildste skrywers geword. Eers het Feniks die verbeelding aangegryp en nou is daar Orion, wat onlangs verskyn het." ("With his thrillers, Deon Meyer quietly became one of the country's most popular writers. First Feniks seized the imagination and now there is Orion, which recently appeared.") (Malan, 2000; our translation)

In contrast, Botma (2000) both recognised the role of WMVS and criticised Orion for certain perceived shortcomings:

"Na die puik Feniks, sy vorige boek, kon jy opgewonde verklaar dat Deon Meyer nie meer net nog een van die hoopvolles op die aanloopbaan is nie, maar dat hy opgestyg het om hom by die geledere van internasionale skrywers van spanningsverhale aan te sluit... Hoewel Meyer met Orion wys dat dit beslis nie 'n totale oorskatting was nie, tref sy derde roman egter van tyd tot tyd 'n lugleegte. Waarskynlik omdat hy dikwels hier te ver afwyk van sy sterk punt die vertel van 'n deeglik nagevorsde, eg Suid-Afrikaanse speur-spanningsverhaal vertoon van sy karakters en wendings weer iets van die ongeloofwardigheid wat sy debuut, Wie met vuur speel, gekenmerk het." ("After the excellent Feniks, his previous book, you can excitedly declare that Deon Meyer isn't just a hopeful anymore, but that he's risen to join the rank of international crime fiction writers... While Meyer shows in Orion that this wasn't a total over-estimation, his third novel sometimes hits a low point. Probably because he often deviates too far from his strong point, the telling of a thoroughly researched, truly South African detective thriller, his characters and 
plot twists again show some of the lack of credibility that characterised his debut, Wie met vuur speel." (Botma, 2000; our translation)

For the publication of Orion in 2000, Meyer followed Bloemhof to Human \& Rousseau, and in them has found the most appropriate local publisher for his work. After restructuring within NB from 2001, Tafelberg became the main imprint for literary fiction, political nonfiction, and children's books, while Human \& Rousseau focuses on popular fiction for the general market. The cover design was modern and attractive, and reviewers appreciated this, commenting, "Moenie weer kom sê daar is nie speurromans wat vergelyk met die bestes uit Europa of Amerika nie. Daar is... Boonop is hierdie een van die mooiste boeke wat ek nog in my hand gehou het. Komplimente aan die uitgewers." ("Don't tell me again that there aren't crime novels that compare with the best from Europe or America. There are... In addition, this is one of the loveliest books I've yet held in my hands. Compliments to the publishers") (Rautenbach, 2000; our translation).

Meyer had by this time been successfully branded as a crime writer. It has been argued that South African literary critics find it hard to categorise his works, but we would argue that he is accepted not only as a popular fiction writer, but also as a literary author. He thus operates at the interface between literary culture and consumer culture - a peculiar position in terms of the global publishing industry. Bourdieu (1985), for instance, distinguishes between the field of restricted production, which trades on symbolic or literary capital, and the field of mass production, which values economic capital. The two fields are seldom reconciled. Orion and its successor, Infanta (LAPA, 2004) were successfully inserted into Afrikaans literary circles through book reviews, and later articles, by academics, book launches (including one at the Nasionale Afrikaanse Letterkundemuseum en Navorsingsentrum, or NALN), and selection for book clubs. Infanta was written as part of Meyer's Master's degree in creative writing, and was supported by the Afrikaans foundation for language and culture (ATKV), and published by their publishing unit, LAPA. A review of Infanta by English literature academic Andries Wessels (2004) shows both Meyer's growing cultural capital as an Afrikaans writer, and the myth-making around Feniks as his debut novel: 
"Deon Meyer se Infanta bevestig die baasskap ... van dié Afrikaanse spanningsverhaalskrywer. Soos sy voorgangers (Feniks, Orion en Proteus) is Infanta ' $n$ kragtoer wat die leser stormenderhand verower en bewys dat Meyer internasionaal in die top-kategorie van spannings- of speurverhaalskrywers hoort" ("Deon Meyer's Infanta confirms the dominance ... of this Afrikaans thriller writer. Like its predecessors (Feniks, Orion and Proteus) Infanta is a tour de force which overpowers the reader and shows that Meyer belongs in the top category of international thriller or crime writers.")

Wessels (2004) went on to point out that none of the books had yet achieved bestselling status: "Wat wel verras, is dat die boeke in hul oorspronklike Afrikaans steeds nie heeltemal blitsverkoper-status bereik nie" ("What is surprising is that the books in their original Afrikaans still haven't really reached bestseller status"; our translation). So what changed in the following few years?

\section{Success factors for bestseller status}

As Figure 1 shows, Meyer's titles have grown in popularity. Bestselling fiction titles depend on a particular combination of factors for their success. According to Sutherland (2007) a bestseller is determined not only by sales, but also by a market's awareness of the author, media exposure, global status, word-of-mouth, adaptions of the works in the form of movies and television series, and displays in bookshops. The bestseller lists also play an integral role in what the market perceives as "good books", and ultimately influence consumers' purchasing decisions. Craighill's (2013) study of the success of the Swedish crime writer, Henning Mankell, emphasises similar aspects, asking, "how did Mankell reach international bestseller status across the globe?" Significantly, she also highlights "strategies enabling small nation authors to navigate the international platform and access global markets", notably the use of a literary agent and the selling of English-language translation rights.

Bloemhof, Meyer's long-time editor, has identified a number of factors accounting for his success as an author: his loyal Afrikaans readership, local awards, international success (which may be seen in the number of translations and awards), and the successful television and film adaptations of his work. He also emphasises the continuity and regular appearance of new titles: "Die tendens die afgelope dekade, waar daar byna elke jaar'n nuwe boek van 
hom op die rakke was, het sy gewildheid verder gevestig" ("The trend over the past decade, where a new book of his appeared on the shelves almost every year, established his popularity still further") (Bloemhof, 2013; our translation). This final factor, of regular output, is significant in maintaining customer loyalty: "as with most products, availability and consistency (rather than absolute quality) are the guiding principles of star-marketed authors" (Royle, Cooper and Stockdale, 1999/2000: 10).

Combining these various approaches, this section will examine key success factors, focusing on the following aspects: the role of the literary agent, the building of international market awareness through the sale of translation and other subsidiary rights, literary awards, and branding decisions. These aspects are all intertwined, but will be separated as much as possible for the sake of discussion. Notably, as mentioned, attention will not be paid to the quality of the writing itself or to the storylines, although these may be significant in themselves in accounting for Meyer's success (see e.g. Primorac, 2011; Torres, 2012).

Figure 1: Overall sales for Meyer's works

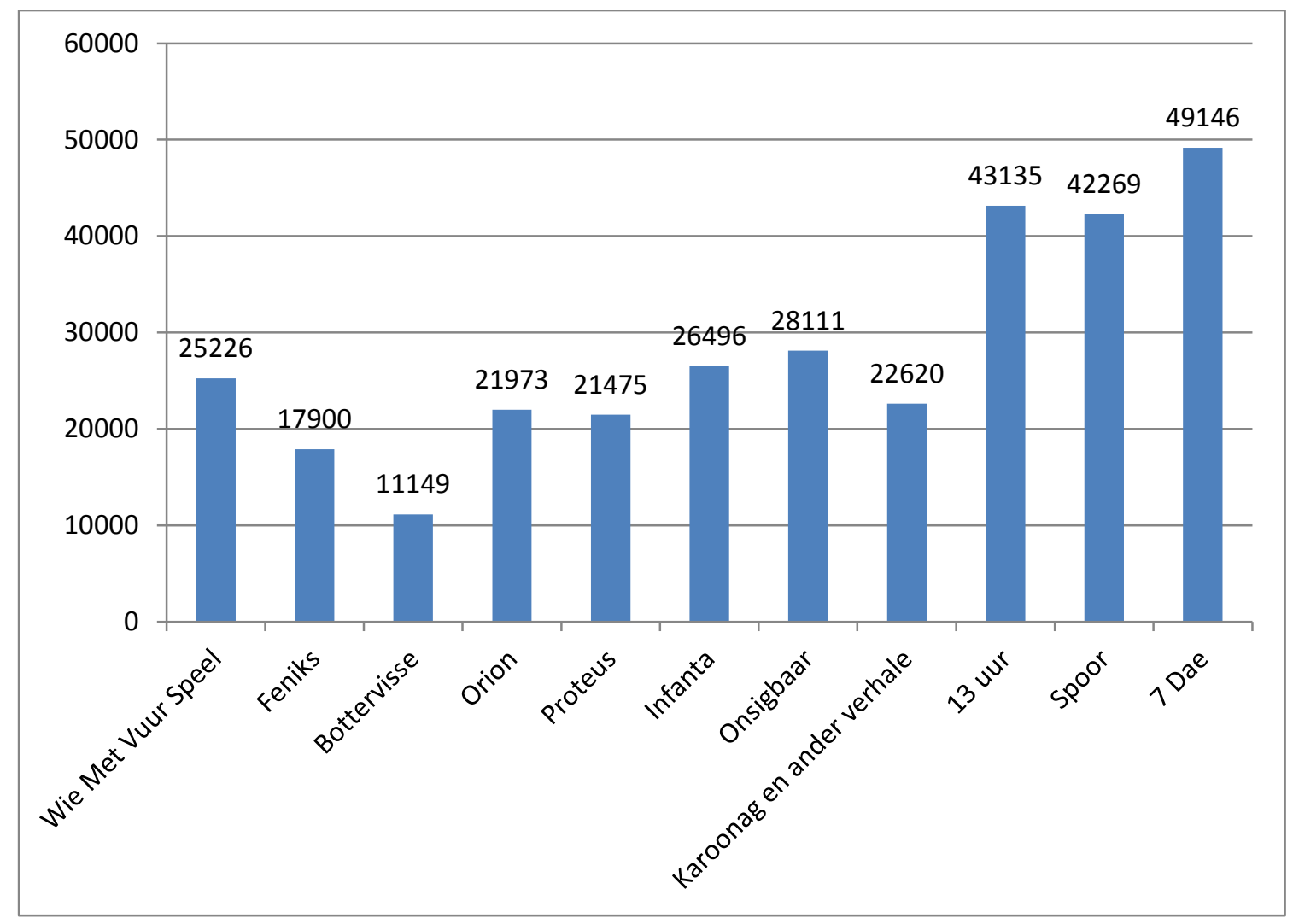

Source: NB Publishers, 2013; LAPA, 2013. Note: these are combined sales figures for all Afrikaans editions of these works. In the case of Bottervisse in die Jêm and Infanta, the figures refer to print totals, not sales figures. 


\section{The role of the literary agent}

While in South Africa it is still possible for authors to work directly with publishers, internationally it is very difficult to build a good relationship without the help of a literary agent. Meyer himself attributes much of his success to his agent: "My second Afrikaans novel attracted the attention of someone who knew my wonderful agent, Isobel Dixon, who managed to sell the translation to a British publisher, Hodder \& Stoughton. That was way back in 1995" (Meyer, 2013). Dixon's involvement and that of the agency she represents, Blake Friedmann, has been crucial in positioning Meyer in the global publishing industry, and if "Meyer's major success has been in breaking through to the international market" (Groenewald 2007), then it may partly be attributed to her.

The relationship was initiated due to personal connections, as Dixon's father-in-law, Danie van Niekerk was the former head of Tafelberg. Dixon (2013) recalls her first encounter with Meyer's work as follows:

I printed out the first English chapters (already translated by Madeleine van Biljon) of Feniks (which became Dead Before Dying) to read on the train back to Cambridge late one evening, just before the Frankfurt Book Fair, and I was so excited by the writing, the character of Mat Joubert, and the suspense, that I immediately offered to take him on (making a last-minute addition to our client lists before the Fair).

As the quote shows, the agent's familiarity with Afrikaans was an important factor, the translation was already in process, and she experienced "that infallible "hair-on-the-back-ofthe-neck' feeling you get when confronted with writing that rings true" (Dixon, 2013). Without such an agent, an author has very little chance of attracting the attention of a good publisher, internationally. A fellow South African crime writer, Margie Orford (2007), has described this pivotal role of the agent:

The South African reading public is small, so for a professional writer international sales are essential. Although I found the first round of sales - brilliantly orchestrated by my agent, Isobel Dixon - overwhelming, especially when I learned that the first German print run would be 100000 copies. I asked Rebecca Servadio Kenan why she thought my work had sold internationally. She was nice enough to say that it was good, that "the stories are gripping, contemporary and of interest whatever one's 
reality". But, she said, and this is key, it is "because you have an agent who is dedicated and thorough and successfully raising your profile".

Once again, we are reminded of the importance of a fruitful business relationship between writer, agent and publisher. Meyer (2013) describes this relationship in positive terms: "She [Dixon] is my agent, my mentor, my advisor and sounding board (my mother, sometimes), and my friend. She plays a huge role in every professional decision I make." She has also given him very good advice regarding his publishing contract, as he has sensibly retained all rights "except publishing rights in the specific language of the contract, for obvious monetary reasons". This has enabled Meyer to license the various subsidiary rights to his works to the most appropriate publishers in the most advantageous way.

Dixon soon licensed rights to Feniks to the Netherlands, France and the UK. But the real breakthrough in terms of Meyer's career came when she sold the English-language translation rights to Hodder. As Dixon (2013) notes, “English editions are vital for any book's success on the international market, especially when you have a source language like Afrikaans, with few proficient readers and translators internationally." The rights to Meyer's titles have now been sold in 27 countries, and few of the translations are based on Afrikaans (usually just German, Norwegian and Dutch). "In other markets like Russia, Sweden, Italy, Spain, Japan, Finland, etc., the translators work from the English edition, and without an 'intermediary' English edition these deals would not be possible" (Dixon, 2013).

\section{International market awareness}

Human has noted that now that Meyer is an international writer, international audiences have new expectations regarding his work, crime fiction and South Africa (RSG 2012). Meyer's books appear to have the unusual ability to keep local audiences interested, while also appealing to an international audience. But this international appeal would not have been possible without the translation of his work into English. The sale of English-language rights to Hodder (under their imprint, Coronet) in 1999 was thus crucial to his global success. 
Hodder acquired British and Commonwealth rights (excluding Canada, as it has a separate licence) in 1999, and went on to acquire further rights as new titles were published. Nick Sayers of Hodder reveals the importance of Meyer's cultural capital by referring to his awards: "Deon is already a bestseller in many countries, including his own, of course, and his nomination for the 2010 CWA International Dagger simply confirms what we already knew - that he is one of the finest crime thriller writers in the world." This sort of rights deal brings Meyer's work to a much wider audience, which grows his market share and general awareness of his novels. In addition, because Hodder is part of Hachette, one of the largest multinational publishing groups, the English-language publication gave Meyer access to much broader and mainstream distribution and access channels, and to a well-oiled marketing machine. Thus, the selection of publisher has influenced Meyer's positioning in the market.

Meyer's English translations were first done by Madeleine van Biljon, and later by Laura Seegers. The rise in international interest had a huge impact on Meyer's own career: "Elke taal wat bykom, bring my nader aan my droom om heeltyds te skryf. Maar ek skryf nooit met ' $n$ oorsese mark in gedagte nie" ("Every language that is added, brings me closer to my dream of writing full-time. But I never write with an overseas market in mind") (cited in Britz, 2000; our translation). Fiona Snyckers (2012) enthuses in this regard:

... while Afrikaans fiction has its own enthusiastic following, it is very unusual for an Afrikaans writer to make the jump over to the English market simply by being translated. Meyer also sets his books in a determinedly South African locale, with no pandering to international readers. Nevertheless, his novels have been a huge hit both at home and overseas ... His narrative is so compelling that it loses nothing in translation and leaves the international reader utterly unbothered by the unfamiliar setting.

The US market was more difficult to enter, and Meyer has noted that this may be because of a lack of familiarity with South Africa in that market. In a recent radio documentary, he explained that it was his US translations that he needed to adapt and change the most. In some instances, he was required to add a glossary, an abstract providing context about South African political history, or even an additional explanatory chapter, in order to make the text more accessible to US readers (RSG, 2012). Perhaps because of such difficulties, and 
in spite of winning an award, Meyer has not yet received outstanding success in the United States. Indeed, a review of his recent novel Trackers argues that, "This powerhouse read, which captures the many facets of modern South Africa, should be the American breakthrough book this talented author deserves" (Publishers' Weekly, 2012).

The US reception of Meyer's work is complicated to assess, in part because translations were not published in the original order in which they were written, as rights were only sold after the publication of several titles. This may be seen on the US cover for Dead before Dying, which brands Meyer as the "author of Devil's Peak" (a later work in South Africa). Reviews thus may refer to Dead before Dying as Meyer's first book or as his third book (it was actually the third to be released in the US), and to a very different publication order:

Layers and layers of criminal history and political intrigue are exposed in Dead at Daybreak, a bulked-up thriller by Deon Meyer ... The reader, however, might prefer less angst and more thought about the state of the nation - something along the philosophical lines of Tiny Mpayipheli, the much superior protagonist of the author's previous novel, Heart of the Hunter (Stasio, 2008).

Figure 3: Cover of US edition of Dead Before Dying

Various of the international reviews refer specifically to the translation, as in the following examples: "The writing is fluent and coherent and full of insight into the problems of South Africa (although the translation is sometimes clumsy and even, occasionally, grammatically suspect)" (Lewin, 2009); "[Meyer] is fortunate in his English translator, K. L. Seegers, who is an inconspicuous presence in this thoughtful and exciting novel" (Cooper, 2007). The selection of publishers for the various translations has been significant, too. For instance, the Dutch publisher Bruna is well-known as a crime fiction publisher, and they have brought his work out as a complete series although they were not his first Dutch publisher (Francken, 2013). Similarly, in France his work has been published by Seuil Policiers, who specialise in crime fiction. This has influenced the positioning of Meyer in the various markets where his books are now sold.

\section{Literary awards}


Meyer argued in 1996, after the publication of his second novel, that he could not be seen as an 'author', but rather as a 'storyteller', as he had not won any literary awards (Engelbrecht, 1996). This situation has certainly changed, as Meyer has now received recognition in a variety of countries. This has contributed to his brand awareness and thus to his international standing and sales. As Squires (2007) observes, winning a literary award has both a commercial and a status impact - it contributes to both the literary and the economic capital of the author - as awards generally lead to immediate sales increases as well as increasing the standing of the author. Publishers use the winning of a literary prize as a marketing tool, in particular through the use of stickers or straplines on the cover. Booksellers also give increased display space to award-winning works, which also usually leads to an increase in sales.

The first form of recognition for Meyer came at home, with Orion winning the ATKV prize and the M-Net book prize in 2001, and Proteus winning the ATKV prize in 2003 . This led to a great deal of publicity, especially in the Afrikaans media. Further prizes, at fairly regular intervals, have ensured that Meyer's work has remained very firmly in the public eye, and has contributed to both his economic and his cultural capital as an author.

Internationally, the winning of awards has also led to increased global attention and sales. One of Meyer's earliest international awards was the French Grand Prix de Littérature Policière, also for Orion, which was published in French as Les Soldats de l'aube in 2003. Since then, he has won further awards in a number of countries, including Germany, the Netherlands, and the United States. While French publishers have not used the awards directly for marketing, in that there is no sticker or strapline on the French titles, the winning of these awards has led to increased publicity. For other languages, stickers are more widely used. For instance, on most of the German titles there is a sticker saying "Deutscher Krimi-Preis", and the Swedish titles have similar stickers regarding a Swedish literary prize. The use of these stickers becomes a key element in the branding of the author and his works. 


\section{Marketing and branding}

As Dixon (2013) notes, "Books will sink without PR and marketing effort and a lot of (her) work as an agent is about pushing for better and more extensive marketing and PR for authors, often as part of deal negotiations too". Deon Meyer is thus perceived and managed as a 'brand'. Human notes the key benefits of a literary brand as being instantly recognisable (awareness), visible (being on display in stores and in media), and ultimately leading to action (through purchasing) (RSG, 2012). Meyer has noted that he was surprised by the amount of money and time invested by his British publisher Hodder \& Stoughton, and their local distributor Jonathan Ball, in promoting his works and in speaking to bookshop staff. According to the publisher, a considerable percentage of books are sold by bookshop staff who guide customer's purchasing decisions (Van Zyl, 2000).

Indeed, Hodder has been very active in marketing Meyer's work. One of their initiatives may be related to the paratext, once again, in that they regularly refresh the cover designs and packaging. In 2013, they began re-issuing Meyer's backlist as a cohesive series, with attractive new covers. This tends to attract further readers, as series are very popular in genre fiction. Hodder's marketing efforts in South Africa have largely been channelled through Jonathan Ball, as the latter serves as a distributor and now fondly refers to Meyer as being one of 'their' authors.

At first, Human \& Rousseau were not as active in terms of marketing. More recently, though, there has been a general improvement in the presentation and marketing of Afrikaans books (Van Zyl, 2000). Thus, recent years have seen H\&R refresh the packaging with reprints of all Meyer's works. As part of the reprint initiative, Wie met vuur speel was re-issued in 2007, based on reader demand for Meyer's earlier works. With its striking new cover (featuring an extreme close-up of a smoking gun) and series identity, some reviewers mistook it for his 'latest' or 'new' title: "Al is dit die enigste boek wat julle dié winter lees, moenie Deon Meyer se nuutste, Wie met vuur speel, misloop nie" ("Even if it's the only book that you read this winter, don't miss Deon Meyer's latest, Wie met vuur speel") (Van der Westhuizen, 2010; our translation). The reviews of the new edition were extremely positive, although some commented on the fact that the author had improved his style over the years (Van der Merwe, 2007). In addition, H\&R have made an effort to keep up with new 
technology, as Meyer's book Spoor was the first Afrikaans fiction title to be made into a book trailer (Huisgenoot, 2011). The trailer for 7 Dae, another bestselling title, was interactive (http://www.youtube.com/watch?v=sby8NVZ5upE).

Several of Meyer's publishers have used comparison marketing, to make him more familiar to their readers by associating him with a well-known brand. For instance, some of the German titles refer to Meyer as "Mankell Südafrikas", or the South African Mankell, referring to the bestselling Swedish crime writer. In contrast, in France, Les soldats de l'aube was produced with a cover strapline saying "Ce polar n'est pas suédois" - "This detective story is not Swedish" - in an attempt to differentiate it from the perceived flood of 'Scandicrime'. France is in fact Meyer's largest market.

In addition to the publishers' marketing, authors play an important part in publicising their work. Meyer regularly praises his publishers and the media for their role in marketing books and writers, but he has been a very shrewd role-player in branding and positioning his work - himself. He notes, "Vir die uitgewer is elke publikasie 'n dobbelspel en 'n groot investering van tyd en geld, sonder enige waarborg van sukses. Die minste wat die skrywer kan doen, is om dit te ondersteun met optredes en onderhoude" ("For the publisher, every publication is a gamble and a big investment of time and money, without any guarantee of success. The least a writer can do is to support this with events and interviews") (LitNet, 2010; our translation). Studies have also shown that readers are more likely to buy a book on the basis of a recommendation or author interview, than a publisher-funded advertising campaign (Van Zyl, 2000):

... the single most common reason for buying a book was the author and it could be argued that this is due to best-selling authors now being aggressively marketed as brand names in their own right. Authors, particularly in mainstream fiction, can achieve high levels of recognition and loyalty (brand name status) from book-buyers. Their appeal is likely to last for some years and their ability to attract a large and loyal fan base gives a level of security for the publisher... (Royle, Cooper and Stockdale, 1999/2000: 9). 
Meyer's well-maintained author website, regular interviews and appearances at events are thus an important aspect of the marketing of his work. Brown (2006: 11) refers to this strategy as expanding the readership of books through "meet the author culture".

Moreover, Meyer realises the important fact of brand reinvention. The way to maintain and grow an audience is to not stagnate and produce 'cookie-cutter' fiction, but to reinvent, adapt and make both the author and the books more interesting. Meyer collaborates with other artists and musicians, is a regular speaker at book festivals, and also does 'genrehopping'. He has published short stories, a cookbook, and a book on his hobby, adventure biking (Dirt Busters, 2013), to name but a few, and he has also written several screenplays for films. In 2013, he appeared as guest editor for the quarterly catalogue of the popular South African book club, Leserskring/Leisure Books, which has a membership in the hundreds of thousands. In addition, he is now launching an online novel, once again reinventing himself and keeping up with trends. These varied initiatives help to keep Meyer's persona in the public eye, and assist with instant name recognition throughout South Africa. As Lamb et. al. (2006) note, "awareness of the brand name and attributes and benefits associated with the recall of the name that become entrenched in consumer's memories ... [is] then used to guide purchasing decisions". Moreover, "€ffective branding spills over to new and other products, leading to faster consumer acceptance" (Lamb et al., 2006: 231-232).

At the same time, Meyer is self-deprecating about this role: "I do self-marketing for two reasons: Because my agent and publisher ask me, and because I find it fun, having worked in advertising for a long time. Is self-marketing important? Not all that much, methinks" (Meyer, 2013). While Meyer thus plays down the importance of self-marketing, it has clearly played a significant role in enhancing his brand as an author. This may not have been done strategically or even consciously, but the fact that Meyer was employed as a journalist and then a brand strategist before 2008 may have been pivotal in successfully shaping his career as writer. This is essential knowledge that not all local writers have. Thus, although he sees himself as an introvert who avoids the limelight, he is doing a very good job in building a strong brand with the help of his local and international publishers, and agent. In an interview with RSG (2012), Meyer says that he grew up with the idea of a writer being in the 
background, and the book being the main marketing medium. He realises that this has changed in the last 20 years, and especially with new technology and as an international author, he cannot hide from his fans anymore. He is grateful for great local and international publishers managing his brand, but feels that the actual book is the most important representation of the brand.

\section{Conclusion}

As this article shows, with careful branding, personal commitment and charisma, media exposure and well-chosen paratext, the "Deon Meyer" brand has been able to reach bestselling status. The team of writer, agent and publisher understands the nature of successful branding - promoting brand awareness by creating a positive experience, while realising that this is a long-term investment. Once readers are aware of the brand they become loyal and ultimately this builds brand equity, i.e. a brand with high awareness, perceived quality and brand loyalty, and considered a valuable asset is realised (Lamb et. al., 2006: 233). Meyer's local following developed first, especially due to his insertion in Afrikaans media networks and literary circles, and the increasing interest shown by academics from 2004 onwards. International sales took off after 2007/2008, due to a combination of factors: above all the role of his literary agent and the English-language versions, but also the sale of translation rights, literary awards, his TV series and improved marketing.

Thus, while many would single out the quality of Meyer's writing as the driving force behind his success, this article seeks to show that without proper marketing, rights sales and positioning in the hearts and minds of readers both nationally and internationally, this author may never have been able to achieve the breakthrough status that he has. Meyer's success is thus a reflection of both his own skills and those of the South African publishing industry. 
Acknowledgements: With thanks to the following for their assistance in providing facts, figures and opinions: Deon Meyer; Isobel Dixon of Blake Friedmann; Etienne Bloemhof, Eloise Wessels and her team at NB; and Esmé at LAPA.

\section{Sources}

Andersson, Muff. 2004. Watching the detectives. Social Dynamics, 30(2): 141-153.

Botma, Gabriel. 2000. Review. Die Burger, 2000/09/06.

Bourdieu, Pierre. 1985. The market of symbolic goods. Poetics, 14(1/2): 13-44.

Britz, Elretha. 2000. Interview. Volksblad, 2000/09/25.

Brown, Stephen (ed.). 2006. Consuming Books: The Marketing and Consumption of Literature. Oxford: Routledge.

Cooper, Natasha. 2007. Review. Times Literary Supplement.

Craighill, Stephanie. 2013. Henning Mankell: European Translation and Success Factors. Publishing Research Quarterly, 29(3): 201-210.

Davis, Geoffrey V. 2013. Old loyalties and new aspirations: the post-apartheid crime fiction of Deon Meyer. In Anja Oed and Christine Matzke (eds). Life is a Thriller: Investigating African Crime Fiction. Berlin: Rudiger Koppe Verlag.

Dixon, Isobel. 2013. Pers. comm. with Samantha Buitendach. 29/10/2013.

Drawe, Claudia. 2013. Cape Town, City of Crime in South African Fiction. Current Writing, 25(2): 186-195.

Francken, Eep. 2013. Een grote glimlach op Schiphol: De Afrikaanse literatuur in Nederland in 2012. Tydskrif vir Geesteswetenskappe, 53(1).

Genette, Gérard. 1991. Introduction to the Paratext. New Literary History, 22(2): 261-272. Groenewald, Yolandi, 2007. A thrill in every language. Mail \& Guardian, 2007/08/10.

Huisgenoot. 2011. Lokprent vir Deon Meyer boek. Online: http://huisgenoot.com/vermaak/lokprent-vir-deon-meyer-boek/ (Accessed 25/10/2013). 'Jaydee'. 2013. Comment on Beeld website, 2013/09/03. Joubert, Emile. 1994. Review. Beeld, 1994/12/13.

Kleyn, AJT. 2013. 'n Sisteemteorietiese kartering van die Afrikaanse literatuur vir die tydperk 2000-2008: Kanonisering in die Afrikaanse literatuur. PhD thesis, University of Pretoria. Lamb, CW., et al. 2006. Marketing. Cape Town: Oxford University Press. LAPA Uitgewers. Pers. comm. with Samantha Buitendach, 25/10/2013. 
Le Roux, Elizabeth. 2013. South African Crime and Detective Fiction in English: A publishing history and bibliography. Current Writing, 25(2): 136-152.

Lewin, Matthew. 2009. Review. The Guardian, 2009/04/17.

Malan, Hannelie. 2000. Hy skryf, want 'n gejeuk moet jy krap. Beeld, 2000/11/03.

Meyer, Deon. 2013. Online: http://www.deonmeyer.com/afrikaans/boeke/vuur.html (Accessed 2/10/2013).

Meyer, Deon. 2013. Pers. comm. with Samantha Buitendach, 2013/10/17.

Meyer. Deon. n.d. Interview, Online: http://www.shotsmag.co.uk/interview view.aspx?interview id=100 $\quad$ (Accessed 2/10/2013).

NB Publishers. 2013. Pers. comm. with Samantha Buitendach, 27/09/2013.

NB Publishers. 2013. Our Authors: Deon Meyer. Online: http://www.nb.co.za/authors/1303 (Accessed 28/10/2013).

Nicol, Mike n.d. Who's Who of South African Crime Writing. Online: http://crimebeat.bookslive.co.za/whos-who-of-south-african-crime-writing/ (Accessed 10/10/2013).

Olivier, Fanie. 2000. 'Orion' 'n ordentlike storie ordentlik vertel. Beeld, 2000/09/25.

Orford, Margie. 2007. Crime writing on the rise. Mail \& Guardian, 2001/11/06.

Pakendorf, Gunther. 1995. Review. Die Burger, 1995/03/22.

Primorac, Ranka. 2011. Dialogues across Boundaries in Two Southern African Thrillers. Journal of Commonwealth Literature, 46(1): 157-172.

Publishers' Weekly. 2011. Trackers. 2011/07/18.

Rautenbach, Elmari. 2000. Review. Volksblad, 2000/10/30.

Royle, J., L. Cooper and R. Stockdale. 1999/2000. Publishers: An investigation into marketing the book as a brand name product. Publishing Research Quarterly, Winter: 3-13.

RSG. 2012. Podcast of documentary on Deon Meyer. Online: www.rsg.co.za/images/upload/sound/klanke/20120112_DOKUMENTR_Deon_Meyer.mp 3 (Accessed 17/10/2013).

Snyckers, Fiona. 2012. Putting SA fiction on the map. Online: http://www.thoughtleader.co.za/fionasnyckers/2012/11/01/putting-sa-fiction-on-themap/ (Accessed 17/10/2013). 
Squires, Claire. 2007. Book marketing and the Booker Prize. In N. Matthews and N. Moody (eds). Judging a Book by its Cover. Farnham: Ashgate: 71-82.

Stasio, Marilyn. 2008. Review. New York Times Book Review, 13/04/2008.

Sutherland, John. 2007. Bestsellers: A very short introduction. Oxford: Oxford University Press.

Torres, Agustín Reyes. 2012. Deon Meyer's Dead before Dying: voices and representation of the new South Africa. ES: Revista de filología inglesa, 33: 271-284.

Van der Merwe, Corli. 2007. Review. Volksblad.

Van der Westhuizen, Alida. 2010. Review. Rapport, 2010/04/30.

Van der Westhuizen, PC. 1995. Review. Beeld, 1995/03/06.

Van Zyl, J. 2000. Blaas af daai stof! Die Burger, 2000/03/22.

Venter, RMR. 2006. Die materiële produksie van Afrikaanse fiksie (1990-2005): 'n empiriese ondersoek na die produksieprofiel en uitgeweryprofiel binne die uitgeesisteem. PhD thesis, University van Pretoria.

Warnes, Christopher. 2012. Writing Crime in the New South Africa: Negotiating Threat in the Novels of Deon Meyer and Margie Orford. Journal of Southern African Studies, 38(4).

Wessels, Andries. 2004. Review. Die Burger, 2004/12/13.

Wessels, Andries. 2007. Problematising the ethical: Deon Meyer's Infanta as hard-boiled crime fiction. Tydskrif vir Letterkunde, 44(2): 104-118. 